ROCZNIKI NAUK SPOEECZNYCH

Tom 13(49), numer 3 - 2021

DOI: https://doi.org/10.18290/rns21493.7

\title{
THE IMPACT OF INTERPLAY \\ BETWEEN FORMAL AND INFORMAL INSTITUTIONS ON THE DEVELOPMENT OF INNOVATION NETWORKS: A COMPARATIVE STUDY OF CEECs
}

\section{INTRODUCTION}

Nowadays, innovations are considered in the literature on the subject to be a crucial growth factor for every national economy (Zasuwa, 2006; Cieślik et al., 2016; Kraftova, Kraft, 2018; Dworak, 2020; Godlewska, 2021). Moreover, Zhang et al. (2012) argue that there is a long-term two-way equilibrium relationship between scientific innovations and economic growth. Unfortunately, majority of the Central and Eastern European countries ${ }^{1}$ (CEECs) like Poland, have weak innovation performance and lag far behind most of European countries (Pałubska, 2011; Dworak, 2020). Furthermore, Wysokińska (2012) underlines that institutional system of the European Union member states like Poland or Hungary, have a key importance for development of entrepreneurship and innovation. In addition, social diversity, cultural creativity or socio-institutional infrastructure and networks are necessary for innovations (Lee et al., 2004; Rodríguez-Pose, Crescenzi, 2008; Godlewska, 2021). Institutions provide stability which is needed for innovative efforts to be successful (Lundvall, 1992). Informal institutions such as culture of cooperation, associate culture, learning culture, ability to carry out institutional changes, coordination, public/private consensus, or productive culture are necessary ingredients of institutional embeddedness of innovation system (Cooke et al., 1997) or innovation network ecosystem.

\footnotetext{
Matgorzata Godlewska, PhD - Warsaw School of Economics in Poland, The Collegium of Business Administration; address for correspondence: al. Niepodległości 162, 02-554 Warszawa; e-mail: malgorzata.godlewska@sgh.waw.pl; ORCID: https://orcid.org/0000-0001-7413-0674.

${ }^{1}$ CEEC is an OECD (2000) statistical term for the group of countries comprising Albania (as a non-UE member excluded from analysis), Bulgaria, Croatia, the Czech Republic, Hungary, Poland, Romania, the Slovak Republic, Slovenia, Estonia, Latvia, and Lithuania.
} 
Meanwhile, innovation networks, as 'cooperative relationships between companies and other actors who seek innovation' are necessary for knowledge and capabilities diffusion, inter-organizational learning, or implementation of innovations (Batterink et al., 2010, p. 50). Innovation networks, according to the literature of the subject may be understood as arrangements of at least three independent organisations or institutions connected with each other by a set of long-term cooperation ties for common implementation of innovation goals (Klimas, 2014) and may accelerate and improve the innovation process (Barsh et al., 2008). On the other hand, institutional pathologies may negatively affect further functioning of innovation networks.

Surprisingly, in Poland, Hungary, Romania, Slovenia, Bulgaria and Croatia, the linkages indicator including innovative SMEs collaboration with each others have been systematically fallen since 2012 (European innovation scoreboard, 2019). One of the possible explanations may be the institutional pathologies occurring inside or outside of the innovation system in the CEECs. Secondly, it may be the effect of incomplete institutional transformation process from centrally planned system to capital market.

The main motivation behind conducting this comparative case study research of CEECs is the question which formal and informal institutions may influence the development of innovation networks in transition economies like the CEECs.

The main research objective is to investigate if CEECs informal institutions have a problem-solving role (assisting in overcoming innovation networks failure), which support formal institutions (via trust in the legal system) and stress the importance of following the rules of innovation laws or have a problem-creating role, which do not support formal institutions or development of innovation networks.

\section{INNOVATION NETWORKS VS. CEECs INSTITUTIONS}

In 1989 communist regime collapsed first in Poland and Hungary, then throughout other CEECs (Berend, 2009). The transition to free market system required a whole new set of institutions and legal rules (Stevens, 1992). Moreover, transition and post transition development differed between CEECs not only due to the differences in institutional, but also in social, cultural, historical, or political factors (Podkaminer, 2013). Furthermore, differences in the institutional framework between CEECs were mainly connected with differences 
in informal institutions such as social norms, values as trust or reciprocity and traditions (Putnam et al., 1993).

CEECs, according to Berend (2009) were never, through their modern history, technology leaders but they adopted new technologies by technology transfer. Berry et al. (2010) pinpoint, that there was a cross national distance between countries like CEECs in economic, financial, political, administrative, cultural, demographic, knowledge, connectedness, and geographic dimensions due to institutions differences. In addition, Edquist and Zabala (2012) argue, following 'Varieties of Capitalism' framework developed by Hall and Soskice (2001), that various set of institutions were associated with different innovation capabilities. However, Taylor (2004) highlights that links between the patterns of innovation and types of capitalism were not so clear.

North (1990) divided institutions by the rule component on: i) formal institutions such as: formal rules and norms like national innovation systems regulations, innovation laws or constitutions and ii) informal institutions such as: culture of innovation and entrepreneurship, norms and values like trust, reciprocity, cooperation, and positive attitude to risk.

It should be highlighted that in the literature, for innovation to occur, very important were informal institutions such as entrepreneurial culture (Hofstede, 2001), high level of trust (Sztompka, 2007), creativity (Chen et al., 2008) and cooperation (Lundvall, 2007; De Propris, 2002). Research done by Phelps (2013) proved that informal institutions such as culture, values or norms stimulate the grassroots energy of entrepreneurship, creativity and innovation and support positive attitude to risk, individualism, cooperation, and self-fulfilment. In consequence, it further supports the development of innovation system and innovation networks ecosystem.

On the other hand, formal institutions such as national or regional innovations systems regulations or innovation law also matter when it comes to encouraging or discouraging the process of innovations and increasing or reducing the incentives to innovate or establish innovation networks (Pelkmans, Renda, 2014; Godlewska, 2021).

Moreover, Shane (1993) highlighted that only interplay between formal and informal institutions may generate synergy effects such as growth of innovativeness of national economy through the enhanced level of previous entrepreneurial activities, especially in the innovation networks. Godlewska (2021), Fuentelsaz et al. (2019) or Wang et al. (2018) came to the same conclusion. Increasing expenditure on innovations by formal institutions should be preceded 
by changes in informal institutions, such as values and norms i.e., greater risk appetite, cooperation, and trust (Shane, 1993, pp. 59-73).

Innovation networks understood as cooperation of entrepreneurs, universities, $\mathrm{R}+\mathrm{D}$ institutions, local governments units, clusters, science and technological parks or centres of knowledge transfer (Czakon, 2012; Klimas, 2014), had much higher impact on successful innovations than investments in research and development (De Propris, 2002). However, in practice, functioning of innovation networks may be associated with various institutional pathologies like: i) a lack of trust, opportunism between network members or self-interest instead of common interest (Williamson, 1993; Cooke, Wills, 1999); ii) network failure (Sarasini, 2015); iii) corruption arising from network management (Frisman, Golden, 2017 ); iv) rent-seeking behaviour between networks members (North et al., 2009); v) weak institutions of intellectual property rights (Demsetz, 1967); vi) a lack of sanctions for breaking formal rules (Godlewska, Morawska, 2020), or vii) free-riding behaviour (Corsaro et al., 2012). That is why it is important to investigate whether CEECs informal institutions have a problem-solving role (assisting in overcoming innovation networks failure), which support formal institutions (via trust in the legal system) and stress the importance of following the rules of innovation laws or have a problem-creating role, which undermine formal institutions.

Therefore, in this paper, based on the most recent studies by Godlewska (2021) and Godlewska and Pilewicz (2018), the following hypothesis was introduced: Informal institutions of CEECs like trust in the legal system, trust in other people, creativity, innovative collaboration among entrepreneurs, corruption or culture do not support formal institutions of CEECs like national innovation system or innovation law.

\section{METHODOLOGICAL APPROACH}

This paper compares the theoretical and empirical achievements of the New Institutional Economies with Innovation Theory and innovation network ecosystem concept in the context of transition economies like the CEECs. To fulfil the aim of this paper, the comparative case study research is conducted and their impact on the development of innovation networks of the CEECs is examined. 
The comparative case study research of CEECs formal institutions include: i) analysis of national innovation systems (NIS) of CEECs or ii) instruments of national innovation law (NIL) of CEECs for years 2004-2019.

The comparative case study research of CEECs informal institutions include: i) value types like conservatism/hierarchy from Schwartz and Bardi (1997) and Lewis (2006); ii) trust in other people or trust in legal systems from the European Social Survey (ESS): Round 4 (2008), Round 8 (2016), Round 9 (2018); iii) the meaning of the world "culture" from the research done by European Commission (2007); iv) innovative SMEs collaborating with others indicator based on preliminary CIS and Eurostat data (2016) from European innovation scoreboard (2019); v) corruption control indicator from The World Bank (2019). Moreover, the Spearman's rank correlation coefficient test between variables was performed and results are presented in the next section.

\section{INSTITUTIONS OF CEECs CONNECTED WITH DEVELOPMENT OF INNOVATION NETWORKS}

In the literature of the subject (Brinkerink, Rondi, 2021; Godlewska, 2021 or Fuentelsaz et al., 2020), there is a heated debate whether only informal institutions are important for the development of entrepreneurship or innovation ecosystem (and innovation networks), or if formal institutions also have a significant impact. Moreover, Williams and Vorley (2015) argue that in some of CEECs like Bulgaria, there is an 'institutional asymmetry' between formal and informal institutions and that informal institutions hampered entrepreneurship and innovation ecosystem. Unfortunately, although formal institutions may change overnight (North, 1990, p. 6), the informal institutions such as culture, values, beliefs, taboos, customs, or traditions are much less variable, and their change can take many years (Williamson, 2000). Furthermore, Fukuyama (2007) argues that without supportive informal institutions, even the best formal institutions would not work properly because formal institutions are embedded in the matrix of informal institutions. Both Helmke and Levitsky (2004) and Grzymala-Busse (2010) argue that informal institutions can support formal ones. However, Godlewska and Pilewicz (2018) or Vaupot and Fornazarič (2021) underline that those informal institutions in majority of CEECs are weak and do not support formal ones.

According to Schwartz and Bardi (1997, pp. 396-397), the Central and Eastern Europe put especially high importance on conservatism and hierarchy values and very low importance on egalitarianism, harmony, intellectual and effective 
autonomy, or mastery values. During the transformation process in the 90 s, the majority of the CEECs, were lacking the key support of formal and informal institutions (Aidis, 2005). In the CEECs low level of trust in people coexist with low level of trust in legal systems (see Table 1).

Table 1. Differences of informal institutions of CEECs

(classified by values) connected with development of innovation networks

\begin{tabular}{|l|c|c|c|c|c|c|}
\hline \multicolumn{1}{|c|}{ Country } & $\begin{array}{c}\text { Value } \\
\text { types }^{1}\end{array}$ & $\begin{array}{c}\text { Trust } \\
\text { in other } \\
\text { people }^{2}\end{array}$ & $\begin{array}{c}\text { Trust in } \\
\text { the legal } \\
\text { system }^{3}\end{array}$ & $\begin{array}{c}\text { Innovative SME } \\
\text { collaborating } \\
\text { with others }\end{array}$ & $\begin{array}{c}\text { The meaning } \\
\text { of the word } \\
\text { "culture"5 }\end{array}$ & $\begin{array}{c}\text { Control of } \\
\text { corruption }^{6}\end{array}$ \\
\hline Bulgaria** & 2 & 3.5 & 3.0 & 24.5 & 1 & 50.96 \\
\hline Romania* & 2 & 3.8 & 3.8 & 5.1 & 1 & 52.40 \\
\hline Latvia* & 0 & 4.1 & 4.0 & 44.1 & 1 & 64.42 \\
\hline Hungary** & 0 & 4.7 & 5.5 & 46.7 & 0 & 59.62 \\
\hline Czechia** & 0 & 4.9 & 5.2 & 114.4 & 0 & 69.23 \\
\hline Croatia* & 1 & 4.2 & 3.1 & 86.5 & No data & 60.10 \\
\hline Slovenia** & 1 & 4.5 & 3.9 & 110.1 & 0 & 80.77 \\
\hline Slovakia* & 1 & 4.0 & 4.2 & 70.1 & 1 & 68.35 \\
\hline Lithuania*** $^{*}$ & 1 & 5.2 & 5.0 & 156.6 & 0 & 68.75 \\
\hline Estonia** & 1 & 5.6 & 5.9 & 217.4 & 0 & 89.90 \\
\hline Poland** & 1 & 4.0 & 4.3 & 32.8 & 0 & 74.52 \\
\hline
\end{tabular}

${ }^{1}$ Value types are based on conservatism (understood as 'emphasis on the status quo, propriety, and restraint of actions or inclinations that might disrupt the solidary group or the traditional order') and hierarchy (understood as 'emphasis on the legitimacy of hierarchical allocation of fixed roles and of resources') values from Schwartz and Bardi (1997) and Lewis (2006). Conservatism answer is 1, hierarchy is 2 , conservatism and hierarchy is $0 .{ }^{2}$ Trust in other people measured from 0 - You cannot be too careful to 10-Most people can be trusted from the European Social Survey (ESS): Round 4 (2008)*; Round 8 (2016)***; Round 9 (2018)**. ${ }^{3}$ Trust in the legal system measured from 0 - No trust at all to 10-Complete trust from the European Social Survey (ESS): Round 4 (2008)*; Round 8 (2016)***; Round 9 (2018)**. ${ }^{4}$ Innovative SMEs collaborating with others indicator (understood as 'number of small and medium sized enterprises with innovation co-operation activities, i.e., those firms that had any cooperation agreements on innovation activities with other enterprises or institutions in the three years of the survey period') based on preliminary CIS and Eurostat data (2016) measured from 0 to from European innovation scoreboard - database (2019). ${ }^{5}$ The meaning of the world "culture" from research study done by European Commission (2007). Traditions and customs answer is 1 , arts and literature or lifestyle is $0 .{ }^{6}$ Control of Corruption measured from 0 to 100 , the higher the value, the better the control from The World Bank (2019).

Source: own compilation based on the literature of the subject. 
This may negatively impact on development of innovation networks and innovation system due to problems with collaboration of entrepreneurs necessary for innovation. Moreover, among the CEECs we may observe differences in informal institutions such as cultures, values, traditions, or norms. European Social Survey Round 9-2018 Edition 1.2 (ESS, 2020) highlighted that the CEECs have a very low levels of trust (except Estonia), much lower than other the EU member states (ESS, 2020). The reason for that may be negative experience of their communist past. However, entrepreneurs or people's perception of institutional quality, trust in other people or trust in institutions is extremely important for innovation process, as well as, for the development of innovation networks.

Schwartz and Bardi (1997) argue that CEECs may be divided due to conservatism and hierarchy values (see Table 1 and Table 2). The first group of countries, e.g. Croatia, Estonia, Lithuania, Poland, Slovakia and Slovenia are classified as conservative countries ${ }^{2}$ with: i) moderate level of trust in other people; ii) low level of trust in the legal system (except Croatia-very low level); iii) moderate level of innovative collaboration among entrepreneurs (except Lithuania-high level and Estonia-very high level); iv) perception of culture as art and lifestyle, or art and literature (except Slovakia); v) high level of corruption control (except Croatia-moderate level); vi) national innovation system (NIS) and national innovation law (NIL) supporting culture and cooperation (Slovenia, Slovakia, Lithuania), cooperation and networking (Poland) or culture and values (Croatia); vii) supportive innovation law; viii) tax incentives for innovation (except Slovakia and Lithuania) and ix) protection of intellectual property (Estonia, Croatia, Slovenia or Slovakia) or innovative public procurement (Poland or Lithuania).

The second group of countries, e.g. Bulgaria and Romania are classified as hierarchical countries with: i) very low level of innovative collaboration among entrepreneurs; ii) low level of trust in other people and low level of trust in legal system; iii) perception of culture as tradition and custom; iv) low level of corruption control; v) NIS and NIL supporting cooperation (in case of Bulgaria also culture and trust); vi) tax incentives for innovation (Romania) or governance (Bulgaria), vii) institutional environment supporting innovation and viii) research professionalisation.

\footnotetext{
${ }^{2}$ For Croatia, Latvia, Lithuania, and Romania, which are not included in research by Schwartz and Bardi (1997), the author classified these countries according to the characteristics of Lewis' research (2006).
} 
Table 2. Interplay between formal and informal institutions of CEECs (classified by values) connected with development of innovation networks

\begin{tabular}{|c|c|c|c|c|c|}
\hline Country & $\begin{array}{l}\text { Value } \\
\text { types }\end{array}$ & $\begin{array}{l}\text { Key factors } \\
\text { of NIS }\end{array}$ & $\begin{array}{c}\text { Key } \\
\text { Instruments } \\
\text { of NIL }\end{array}$ & $\begin{array}{c}\text { Informal } \\
\text { institutions } \\
\text { supported by } \\
\text { NIL or NIS }\end{array}$ & $\begin{array}{c}\text { Key formal } \\
\text { Institutions } \\
\text { initiatives }\end{array}$ \\
\hline Bulgaria & Hierarchy & $\begin{array}{l}\text { Institutional } \\
\text { environment }\end{array}$ & Governance & $\begin{array}{c}\text { Culture; } \\
\text { cooperation; } \\
\text { trust } \\
\end{array}$ & $\begin{array}{l}\text { National Innovation } \\
\text { Fund; National } \\
\text { Innovation Council }\end{array}$ \\
\hline Romania & Hierarchy & $\begin{array}{l}\text { Institutional } \\
\text { environment }\end{array}$ & $\begin{array}{c}\text { Tax incentives for } \\
\text { innovation }\end{array}$ & $\begin{array}{l}\text { Cooperation; } \\
\text { networks }\end{array}$ & $\begin{array}{c}\text { Research } \\
\text { management } \\
\text { professionalization }\end{array}$ \\
\hline Latvia & $\begin{array}{c}\text { Conservatism, } \\
\text { Hierarchy }\end{array}$ & Law & State Aid & $\begin{array}{c}\text { Cooperation; } \\
\text { networking }\end{array}$ & $\begin{array}{c}\text { Internationalization } \\
\text { of science }\end{array}$ \\
\hline Hungary & $\begin{array}{l}\text { Conservatism, } \\
\text { Hierarchy }\end{array}$ & Culture; law & $\begin{array}{l}\text { Institutional } \\
\text { environment }\end{array}$ & $\begin{array}{l}\text { Networking, } \\
\text { cooperation, } \\
\text { values, culture }\end{array}$ & $\begin{array}{l}\text { Reform of the } \\
\text { institutional system }\end{array}$ \\
\hline Czechia & $\begin{array}{c}\text { Conservatism, } \\
\text { Hierarchy }\end{array}$ & Law & $\begin{array}{c}\text { Tax incentives for } \\
\text { innovation, } \\
\text { governance }\end{array}$ & $\begin{array}{l}\text { Networking, } \\
\text { cooperation }\end{array}$ & $\begin{array}{l}\text { Intellectual property } \\
\text { protection }\end{array}$ \\
\hline Croatia & Conservatism & $\begin{array}{l}\text { Law, research } \\
\text { partnerships, } \\
\text { commercializat } \\
\text { ion of research }\end{array}$ & $\begin{array}{l}\text { State aid; Tax } \\
\text { incentives for } \\
\text { innovation; } \\
\text { governance }\end{array}$ & $\begin{array}{l}\text { Values; } \\
\text { cooperation }\end{array}$ & $\begin{array}{l}\text { Intellectual property } \\
\text { protection }\end{array}$ \\
\hline Slovenia & Conservatism & Law & $\begin{array}{l}\text { Tax incentives for } \\
\text { innovation, } \\
\text { governance, } \\
\text { financial } \\
\text { instruments }\end{array}$ & $\begin{array}{l}\text { Culture; } \\
\text { cooperation }\end{array}$ & $\begin{array}{l}\text { Intellectual property } \\
\text { protection }\end{array}$ \\
\hline Slovakia & Conservatism & Law & $\begin{array}{l}\text { Financial } \\
\text { instruments }\end{array}$ & $\begin{array}{c}\text { Culture; } \\
\text { cooperation }\end{array}$ & $\begin{array}{l}\text { Intellectual property } \\
\text { protection }\end{array}$ \\
\hline Lithuania & Conservatism & $\begin{array}{l}\text { Law; creative } \\
\text { society }\end{array}$ & $\begin{array}{l}\text { Governance, } \\
\text { institutional } \\
\text { environment, } \\
\text { financial } \\
\text { instruments }\end{array}$ & $\begin{array}{l}\text { Networking, } \\
\text { cooperation, } \\
\text { culture }\end{array}$ & $\begin{array}{l}\text { Innovation Support } \\
\text { Fund; innovative } \\
\text { public procurement }\end{array}$ \\
\hline Estonia & Conservatism & $\begin{array}{l}\text { Law; } \\
\text { cross-border } \\
\text { cooperation }\end{array}$ & $\begin{array}{l}\text { EU Structural } \\
\text { Funds, Tax } \\
\text { incentives for } \\
\text { innovation }\end{array}$ & Cooperation & $\begin{array}{l}\text { Intellectual property } \\
\text { protection }\end{array}$ \\
\hline Poland & Conservatism & $\begin{array}{l}\text { Law; } \\
\text { innovation } \\
\text { dual use }\end{array}$ & $\begin{array}{c}\text { Tax incentives for } \\
\text { innovation }\end{array}$ & $\begin{array}{l}\text { Networking, } \\
\text { cooperation }\end{array}$ & $\begin{array}{c}\text { Business } \\
\text { Constitutions; } \\
\text { Innovativeness } \\
\text { public procurement }\end{array}$ \\
\hline
\end{tabular}

Source: own compilation based on case study research of CEECs national innovation systems and national innovation laws; conservative and hierarchical values from Schwartz and Bardi (1997) and Lewis (2006). 
The third group of countries, e.g. the Czech Republic, Latvia and Hungary are classified both as conservative and as hierarchical countries with: i) low level of trust in other people; ii) moderate level of trust in the legal system; iii) low level of innovative collaboration among entrepreneurs (except Czechia-moderate); iv) perception of culture as art and literature (except Latvia); v) moderate level of corruption control; vi) NIS and NIL supporting cooperation and networking (Hungary also culture and national traditional values); vii) supporting innovation law (except Hungary - also culture of innovation); viii) state aid (Latvia), institutional environment (Hungary) and tax incentives for innovation (Czechia) and ix) internalisation of science (Latvia), reform of institutional system (Hungary) and intellectual property protection (Czechia).

In addition, there is a strong correlation (see Table 3) between value type and innovative collaborations among entrepreneurs, as well as between value type and corruption control. Surprisingly, conservative countries have higher level of innovative collaboration among entrepreneurs or higher level of corruption control compared to hierarchical or conservative-hierarchical CEECs. Not surprisingly, there is no correlation between value type and trust in other people, trust in the legal system, or world "culture" (see Table 3). This mean that informal institutions like trust or culture are weak in the majority of CEECs and are not able to support formal institutions like national innovation system or innovation law.

Table 3. Coefficient correlation between value types and trust, collaboration, culture, and corruption

\begin{tabular}{|c|c|c|c|c|c|c|}
\hline \multicolumn{2}{|c|}{ Spearman's rho } & $\begin{array}{c}\text { Trust in other } \\
\text { people }\end{array}$ & $\begin{array}{c}\text { Trust in the } \\
\text { legal system }\end{array}$ & $\begin{array}{c}\text { Innovative SMEs } \\
\text { collaborating } \\
\text { with others }\end{array}$ & $\begin{array}{c}\text { The word } \\
\text { "culture" }\end{array}$ & $\begin{array}{c}\text { Corruption } \\
\text { control }\end{array}$ \\
\hline \multirow{2}{*}{$\begin{array}{c}\text { Value } \\
\text { types }\end{array}$} & $\begin{array}{c}\text { Correlation } \\
\text { coefficient }\end{array}$ & 0.453 & 0.291 & $\mathbf{. 6 3 3}^{*}$ & 0.346 & $\mathbf{. 7 2 4}^{*}$ \\
\cline { 2 - 7 } & Sig. (2-tailed) & 0.161 & 0.385 & 0.037 & 0.297 & 0.012 \\
\hline
\end{tabular}

* Correlation is significant at the 0.05 level (2-tailed).

Source: own compilation. 
Informal institutions, according to the literature of the subject, may have a problem-solving role, which assists in overcoming innovation networks failure or supports formal institutions such as innovation law via trust in the legal system or entrepreneur's collaboration. On the other hand, informal institutions, according to the literature of the subject, may have a problem-creating role, which may accelerate failure of innovation networks or undermine the formal institutions via lack of trust in legal systems or in other people, opportunism, rent seeking behaviour or corruption. The key question is: which roles do informal institutions play in case of innovation networks?

The case study research of national innovations system regulations and national innovation law of CEECs highlight that these regulations are undermined by weak informal institutions, like, for example: i) modest level of trust of other people in hierarchy and hierarchy-conservatism CEECs, ii) low level of trust of CEECs' citizens in legal systems in hierarchy CEECs; iii) low level of corruption control in hierarchy CEECs; iv) low level of collaboration among entrepreneurs in hierarchy or hierarchy-conservatism CEECs or v) entrepreneurial or innovative culture does not have a primary importance in hierarchy and hierarchy-conservatism CEECs (except Bulgaria and Hungary).

The result of the current study, namely that informal institutions of CEECs like trust in the legal system, trust in other people, innovative collaboration among entrepreneurs, corruption or culture do not support formal institutions of the CEECs like national innovation system or innovation law. These institutions are crucial for development of innovation networks, what is in line with Hofstede (1980, 2001), who examined dimensions of culture such as individualism/collectivism, uncertainty avoidance, power distance, short-term orientation/long-term orientation, indulgence/restraint or femininity/masculinity. CEECs, in line with the results of Hofstede's research (1980, 2001), are countries with: i) a collectivistic nature (except Czechia, Estonia, Hungary or Lithuania,); ii) high levels of uncertainty (except Czechia, Estonia, Lithuania or Slovakia); iii) high power distance (except Estonia or Lithuania); iv) femininity (except Hungary, Poland or Slovakia) and a restrained culture. When viewed together with the results of this study such as the modest level of trust of other people in hierarchy and hierarchy-conservatism, low level of trust of CEECs' citizens in legal systems in hierarchy CEECs, low level of corruption control in hierarchy CEECs or low level of collaboration among entrepreneurs in hierarchy or hierarchy-conservatism CEECs, this may explain why CEECs are not leaders when it comes to innovation networks. That is why it is so important to strength the informal institutions of CEECs because only interplay between formal and informal institutions may generate synergy effects such as growth 
of innovativeness of national economy through the enhanced level of previous entrepreneurial activities, especially in the innovation networks (Shane, 1993).

Zhao et al. (2020) argue that countries with weak informal institutions should introduce a risk guarantee mechanism i.e., a national innovation insurance fund to support innovation process and development of innovation networks later. Such fund may promote the innovation process at different levels.

\section{CONCLUSION}

Interplay between formal and informal institutions has a significant importance for the development of CEECs innovation networks because informal institutions may support or undermine formal ones.

The results of case study research of CEECs' national innovations system and innovation law, supported by ranking of World Governance Indicators 2018 or European Social Survey Round 9 Edition 1.2, 2020 suggests that most CEECs' informal institutions do not support or enforce the formal institutions. The explanation for the lack of enforcement by informal institutions may be the fact that, based on European Social Survey Round 9 Edition 1.2, 2020, CEECs' citizens have a low level of trust in other people, and do not see the need for strict following of formal rules. Hence, informal institutions do not have a problem-solving role in the case of development of CEECs innovation networks. Moreover, the formal regulations of innovation networks of CEECs are undermined by weak informal institutions like, for example: i) modest level of trust of other people in hierarchy and hierarchy-conservatism CEECs, ii) low level of trust of CEECs' citizens in legal systems in hierarchy CEECs; iii) low level of corruption control in hierarchy CEECs; iv) low level of collaboration among entrepreneurs in hierarchy or hierarchy-conservatism CEECs or v) entrepreneurial or innovative culture does not have a primary importance in hierarchy and hierarchy-conservatism CEECs (except Bulgaria and Hungary). These weak informal institutions of CEECs are inherited form centrally planned economy of past communist states and suffer from incomplete transformation because a change in informal institutions is a very lengthy process unlike the change of formal ones.

Only CEECs based on conservatism values like Croatia, Estonia, Lithuania, Poland, Slovakia and Slovenia have: i) moderate level of trust in other people; ii) moderate level of innovative collaboration among entrepreneurs (except Lithuania-high level and Estonia — very high level); iii) high level of corruption 
control (except Croatia-moderate level); iv) national innovation system (NIS) and innovation law (IL) supporting culture and cooperation (Slovenia, Slovakia, Lithuania), cooperation and networking (Poland) or culture and values (Croatia); v) supportive innovation law; vi) tax incentives for innovation (except Slovakia and Lithuania) and vii) protection of intellectual property (Estonia, Croatia, Slovenia or Slovakia) or innovative public procurement (Poland or Lithuania).

The obtained results may improve the understanding of the significance of institutional interplay for the development of innovation networks of the CEECs. Practical policy recommendations, following Zhao et al. (2020), is to introduce a risk guarantee mechanism i.e., a national innovation insurance fund. Such fund may promote the innovation process at different levels, which may influence the development of innovation networks later.

Due to limitations in the currently available data, the paper did not analyse a wider range of variables within formal institutions and focused only on the analysis of national innovation systems and instruments of innovation law of CEECs for years 2004-2019. Moreover, due to limitations in the currently available data of informal institutions analysed data have inconsistent period from year 2007 for the meaning of the world "culture" to year 2019 for corruption control indicator.

\section{REFERENCES}

Aidis R. (2005), Entrepreneurship in Transition Countries: A Review, Centre for the Study of Economic and Social Change in Europe, Working Paper, 61, https://www.researchgate.net/publication/ 24129734_Entrepreneurship_in_Transition_CountriesA_Review[Accessed:18.04.2021].

Barsh J., Capozzi M. M., Dawidson J. (2008), Leadership and Innovation, The McKinsey Quarterly, 1, https://immagic.com/eLibrary/ARCHIVES/GENERAL/MCKNSYUS/ M080104B.pdf [Accessed: 18.04.2021].

Batterink M., Wubben E., Klerkx L., Omta, O. (2010), Orchestrating Innovation Networks: The Case of Innovation Brokers in the Agri-Food Sector, Entrepreneurship and Regional Development, 1(22), pp. 47-76, https://accessed.org/10.1080/08985620903220512.

Berend I. T. (2009), From the Soviet Bloc to the European Union. The Economic and Social Transformation of Central and Eastern Europe since 1973, Cambridge: Cambridge University Press.

Berry H., Guillén M., Zhou N. (2010), An Institutional Approach to Cross-National Distance, Journal of International Business Studies, 41(9), pp. 1460-1480, https://doi.org/10.1057/jibs.2010.28.

Brinkerink J., Rondi E. (2021), When Can Families Fill Voids? Firms' Reliance on Formal and Informal Institutions in R\&D Decisions, Entrepreneurship Theory and Practice, 45(2), pp. 291-318, DOI: $10.1177 / 1042258719899423$. 
Chen M. H., Chang Y. C., Hung S. C. (2008), Social Capital and Creativity in $R$ \& D Project Teams, R \& D Management, 38(1), pp. 21-34, https://doi.org/10.1111/j.1467-9310.2007.00494.X.

Cieślik A., Michałek J. J., Szczygielski K. (2016), Innovations and Export Performance: Firm-level Evidence from Poland, Entrepreneurial Business and Economics Review, 4(4), pp. 11-28, http://dx.doi.org/10.15678/EBER.2016.040402.

Cooke P., Gomez Uranga M., Etxeberria G. (1997), Regional Innovation Systems: Institutional and Organizational Dimensions, Research Policy, 26(4-5), pp. 475-491, https://doi.org/10.1016/S00487333(97)00025-5.

Cooke P., Wills D. (1999), Small Firms, Social Capital and the Enhancement of Business Performance Through Innovation Programmes, Small Business Economics, 13(3), pp. 219-234, https://doi.org/10.1023/A:1008178808631.

Corsaro D., Cantù C., Tunisini A. (2012), Actors' Heterogeneity Innovation Networks, Industrial Marketing Management, 41(5), pp. 780-789, https://doi.org/10.1016/j.indmarman.2012.06.005.

Czakon W. (2012), Sieci w zarzadzaniu strategicznym, Warszawa: Wolters Kluwer.

Demsetz H. (1967). Toward a Theory of Property Rights, American Economic Review, 57(2), pp. 347-359.

De Propris L. (2002), Types of Innovation and Inter-firm Co-operation, Entrepreneurship \& Regional Development, 14(4), pp. 337-353, DOI: 10.1080/08985620210144974.

Dworak E. (2020), The Innovation Gap Between the Polish Economy and the European Union, Comparative Economic Research, Central and Eastern Europe, 23(3), pp. 63-73, https://doi.org/10.18778/1508-2008.23.20.

Edquist C., Zabala J. (2012), Knowledge-Intensive Entrepreneurship, National Systems of Innovation and European Varieties of Capitalism: A Conceptual Framework, AEGIS Technical report, https://www.researchgate.net/publication/271074148_Knowledge-intensive_Entrepreneurship_ National_Systems_of_Innovation_and_European_Varieties_of_Capitalism_A_Conceptual_ Framework [Accessed: 18.04.2021].

European innovation scoreboard (2019), Database, https://op.europa.eu/en/publication-detail//publication/d156a01b-9307-11e9-9369-01aa75ed71a1/language-en/format-PDF/source-136061387 [Accessed: 18.04.2021].

Frisman R., Golden M. A. (2017), Corruption. What Everyone Needs to Know, Oxford: Oxford University Press.

Fuentelsaz L., Garrido E., Maicas J. P. (2020), The Effect of Informal and Formal Institutions on Foreign Market Entry Selection and Performance, Journal of International Management, 26(2), pp. 1-17, https://doi.org/10.1016/j.intman.2020.100735.

Fuentelsaz L., González C., Maicas J. P. (2019), Formal Institutions and Opportunity Entrepreneurship. The Contingent Role of Informal Institutions, BRQ Business Research Quarterly, 22(1), pp. 5-24, https://doi.org/10.1016/j.brq.2018.06.002.

Fukuyama F. (2007), Development and the Limits of Institutional Design, [in:] N. Dinello, V. Popov, Political Institutions and Development Failed Expectations and Renewed Hopes, Cheltenham, UK; Northampton, MA: Edward Elgar Publishing Ltd., pp. 1-31, http://www1.worldbank.org/ publicsector/anticorrupt/feb06course/institutionalAgenda.pdf.

Godlewska M. (2021), The Impact of Interplay Between Formal and Informal Institutions on Innovation Performance: Evidence from CEECs, Inzinerine Ekonomika-Engineering Economics, 32(1), pp. 15-26, http://doi.org/10.5755/j01.ee.32.1.27390. 
Godlewska M., Morawska S. (2020), Development of Local and Regional Entrepreneurship-which Institutions Matter? Evidence from Poland, Economic Research-Ekonomska Istrazivanja, 33(1), pp. 1017-1035, https://doi.org/10.1080/ 1331677X.2018.1553680.

Godlewska M., Pilewicz T. (2018), The Impact of Interplay Between Formal and Informal Institutions on Corporate Governance Systems: A Comparative Study of CEECs, Comparative Economic Research. Central and Eastern Europe, 21(4), pp. 85-104, https://doi.org/10.2478/cer-2018-0028.

Grzymala-Busse A. (2010), The Best Laid Plans: The Impact of Informal Rules on Formal Institutions in Transitional Regimes, Studies in Comparative International Development, 45(3), pp. 311-333, https://doi.org/10.1007/s12116-010-9071-y.

Hall P. A., Soskice D. (Eds.) (2001), Varieties of Capitalism, The Institutional Foundations of Comparative Advantage, Oxford: Oxford University Press.

Helmke G., Levitsky S. (2004). Informal Institutions and Comparative Politics: A Research Agenda, Perspectives on Politics, 2(4), pp. 725-740, https://doi.org/10.1017/S1537592704040472.

Hofstede G. (1980), Culture's Consequences: International Differences in Work-Related Values, London: Sage Publications.

Hofstede G. (2001), Culture's Consequences, Thousand Oaks: Sage Publications.

Klimas P. (2014), Sieci innowacji. Implikacje bliskości organizacyjnej, Katowice: Wydawnictwo Uniwersytetu Ekonomicznego w Katowicach.

Kraftova I., Kraft J. (2018), The Relationship Between Pro-Innovation Factors and the Performance of the European Union Member States and their Regions, Engineering Economics, 29(4), pp. 424-433, https://doi.org/10.5755/j01.ee.29.4.19703.

Lee S. Y., Florida R., Acs Z. (2004), Creativity and Entrepreneurship: A Regional Analysis of New Firm Formation, Regional Studies, 38(8), pp. 879-891, https://doi.org/10.1080/0034340042000280910.

Lewis R. D. (2006), When Cultures Collide: Leading Across Cultures, London: Nicholas Brealey International.

Lundvall B. A. (1992), National Systems of Innovation: Towards a Theory of Innovation and Interactive Learning, London: Pinter.

Lundvall B. A. (2007), National Innovation Systems-Analytical Concept and Development Tool, Industry and Innovation, 14(1), pp. 95-119, DOI: 10.1080/13662710601130863.

North D. C. (1990), Institutions, Institutional Change, and Economic Performance, New York, NY: Cambridge University Press.

North D. C., Wallis J., Weingast B. (2009), Violence and Social Orders: A Conceptual Framework for Interpreting Recorded Human History, Cambridge: Cambridge University Press.

Pałubska D. (2011), Innovation Performance in Poland and Polish Companies, Comparative Economic Research, Central and Eastern Europe, 14(2), pp. 125-141, https://doi.org/10.2478/v10103-011-0014-2.

Pelkmans J., Renda A. (2014), How Can EU Legislation Enable and/or Disable Innovation. European Commission, https://ec.europa.eu/futurium/en/system/files/ged/39-how_can_eu_legislation_ enable_and-or_disable_innovation.pdf [Accessed: 18.04.2021].

Phelps E. S. (2013), Mass Flourishing: How Grassroots Innovation Created Jobs, Challenge, and Change, Princeton: Princeton University Press.

Podkaminer L. (2013), Development Patterns of Central and East European Countries (in the Course of Transition and Following EU Accession), Research Report No. 388, The Vienna Institute for International Economic Studies, https://www.wiiw.ac.at/development-patterns-ofcentral-and-east-european-countries-in-the-course-of-transition-and-following-eu-accession-dlp-2985.pdf [Accessed: 18.04.2021]. 
Putnam R. D., Leonardi R., Nanetti, R. (1993), Making Democracy Work: Civic Traditions in Modern Italy, Princeton: Princeton University Press.

Rodríguez-Pose A., Crescenzi R. (2008), Research and Development, Spill overs, Innovation Systems, and the Genesis of Regional Growth in Europe, Regional Studies, 42(1), pp. 51-67, https://doi.org/10.1080/00343400701654186.

Sarasini S. (2015), (Failing to) Create Eco-innovation Networks: The Nordic Climate Cluster, Technology Analysis \& Strategic Management, 27(3), pp. 283-299, https://doi.org/10.1080/ 09537325.2014.983894.

Schwartz S. H., Bardi A. (1997), Influences of Adaptation to Communist Rule on Value Priorities in Eastern Europe, Political Psychology, 18(2), pp. 385-410, https://doi.org/10.1111/0162-895X.00062.

Shane S. (1993), Cultural Influences on National Rates on Innovation, Journal of Business Venturing, 8(1), pp. 59-73, https://doi.org/10.1016/0883-9026(93)90011-S.

Stevens C. (1992), Introduction, [in:] C. Stevens, J. Kennan (Eds.), Reform in Eastern Europe and the Developing Country Dimension, London: Overseas Development Institute.

Sztompka P. (2007), Zaufanie, fundament spoteczeństwa, Warszawa: Znak.

Taylor M. (2004), Empirical Evidence Against Varieties of Capitalism's Theory of Technological Innovation, International Organization, 58(3), pp. 601-631, DOI: 10.1017/S0020818304583066.

The World Bank (2019), World Governance Indicators 2018, https://datacatalog.worldbank.org/ dataset/worldwide-governance-indicators [Accessed: 18.04.2021].

Vaupot Z., Fornazarič M. (2021), Press and Informal Institutions as FDI Barriers: What Changed in Slovenia Between 1992 and 2018, Post-Communist Economies, DOI: 10.1080/14631377. 2021.1886753.

Wang H., Lu W., Söderlund J., Chen K. (2018), The Interplay Between Formal and Informal Institutions in Projects: A Social Network Analysis, Project Management Journal, 49(4), pp. 20-35, DOI: $10.1177 / 8756972818781629$.

Williams N., Vorley T. (2015), Institutional Asymmetry: How Formal and Informal Institutions Affect Entrepreneurship in Bulgaria, International Small Business Journal, 33(8), pp. 840-861, DOI: 10.1177/0266242614534280.

Williamson O. E. (1993), Opportunism and Its Critics, Managerial and Decision Economics, 14(2), pp. 97-107, https://doi.org/10.1002/mde.4090140203.

Williamson O. E. (2000), The New Institutional Economics: Taking Stock, Looking Ahead, Journal of Economic Literature, 38(3), pp. 595-613.

Wysokińska Z. (2012), European Union Entrepreneurship and Innovativeness Support Policy for Businesses, Comparative Economic Research. Central and Eastern Europe, 15(2), pp. 5-29, https://doi.org/10.2478/v10103-012-0007-9.

Zasuwa G. (2006), Zmiany innowacyjne w przedsiębiorstwach z nowych państw Unii Europejskiej, Roczniki Nauk Społecznych, 34(3), pp. 219-228.

Zhang L., Song W., He J. (2012), Empirical Research on the Relationship Between Scientific Innovation and Economic Growth in Beijing, Technology and Investment, 3(3), pp. 168-173, DOI: $10.4236 /$ ti.2012.33023.

Zhao A., Sun Z., Guan H., Jia J. (2020), Research on the Evolution of Innovation Behavior of New Generation Entrepreneurs in Different Scenarios, Technological and Economic Development of Economy, 26(5), pp. 1098-1124, https://doi.org/10.3846/tede.2020.12373. 


\title{
THE IMPACT OF INTERPLAY BETWEEN FORMAL AND INFORMAL INSTITUTIONS ON THE DEVELOPMENT OF INNOVATION NETWORKS: A COMPARATIVE STUDY OF CEECs
}

\author{
Summary
}

The aim of this paper is to present the results of comparative case study research concerning the impact of the interplay between formal and informal institutions on the development of innovation networks of the Central and Eastern European Countries (CEECs). The primary contribution this article makes is to link the literature on the interplay between institutions related to innovation networks in a broad range of economies in transition like CEECs. This paper provides an understanding of how interplay between these institutions may influence the development of innovation networks of CEECs. Practical policy recommendations are to introduce a risk guarantee mechanism, which may promote the innovation process at different levels and influence the development of innovation networks later.

Keywords: innovation networks; formal institutions; informal institutions; Central and Eastern European countries; comparative case study.

\section{WPŁYW ODDZIAŁYWANIA INSTYTUCJI FORMALNYCH I NIEFORMALNYCH NA ROZWÓJ SIECI INNOWACJI: STUDIUM PORÓWNAWCZE PAŃSTW EUROPY ŚRODKOWEJ I WSCHODNIEJ}

\section{Streszczenie}

Głównym celem niniejszego artykułu jest przedstawienie wyników badań porównawczych nad wpływem wzajemnego oddziaływania między instytucjami formalnymi i nieformalnymi na rozwój sieci innowacji w państwach Europy Środkowej i Wschodniej (EŚiW). Najważniejszym aspektem tego artykułu jest powiązanie literatury odnoszącej się do tych zagadnień z problemami gospodarek w okresie przejściowym, takich jak w państwach EŚiW. Artykuł ukazuje, w jaki sposób wzajemne oddziaływanie między instytucjami formalnymi i nieformalnymi może wpływać na rozwój sieci innowacji w tych państwach. Praktyczne rekomendacje dla polityki innowacyjnej dotyczą wprowadzenia mechanizmu gwarancji ryzyka związanego z procesem innowacji, który może promować proces innowacji na różnych poziomach i tym samym w okresie późniejszym wpłynąć na rozwój sieci innowacji.

Słowa kluczowe: sieci innowacji; instytucje formalne; instytucje nieformalne; państwa Europy Środkowo-Wschodniej; porównawcze studium przypadku. 